\title{
Modeling Long-Term Water Quality IMPACT OF STRUCTURAL BMPS
}

\author{
K. S. Bracmort，M. Arabi，J. R. Frankenberger， B. A. Engel， J. G. Arnold
}

\begin{abstract}
Structural best management practices (BMPs) that reduce soil erosion and nutrient losses have been recommended and installed on agricultural land for years. A structural BMP is expected to be fully functional only for a limited period after installation, after which degradation of the BMP is likely to lead to a reduction in the water quality improvement provided by the BMP. Assessing the impact of BMPs on water quality is of widespread interest, but no standard methods exist to determine the water quality impact of structural BMPs, particularly as the impact changes through time. The objective of this study was to determine the long-term ( 20 year) impact of structural BMPs in two subwatersheds of Black Creek on sediment and phosphorus loads using the Soil and Water Assessment Tool (SWAT) model. The BMPs were represented by modifying SWAT parameters to reflect the impact the practice has on the processes simulated within SWAT, both when practices are fully functional and as their condition deteriorates. The current condition of the BMPs was determined using field evaluation results from a previously developed BMP condition evaluation tool. Based on simulations in the two subwatersheds, BMPs in good condition reduced the average annual sediment yield by $16 \%$ to $32 \%$ and the average annual phosphorus yield by $10 \%$ to $24 \%$. BMPs in their current condition reduced sediment yield by only $7 \%$ to $10 \%$ and phosphorus yield by $7 \%$ to $17 \%$.
\end{abstract}

Keywords. Conservation effects, Phosphorus, Sediment, SWAT, Watershed modeling.

$\mathrm{B}$ est management practices (BMPs) are routinely used to reduce nonpoint-source pollution resulting from agricultural activities and improve water quality. Studies have demonstrated how structural management practices can improve water quality, but the duration of their effectiveness and performance is largely unknown. Although a "design life" has been established by the USDA Natural Resources Conservation Service for most structural BMPs (e.g., USDA-NRCS, 2004), the ability of a BMP to function effectively throughout its assigned design life is uncertain, and its continued effectiveness past the design life is unknown. Quantifying the impact some 25 years after BMPs are installed would provide insight into water quality improvement taking place over time due to BMP implementation.

Watershed modeling is one approach to analyzing the water quality impact, both short and long term, of BMP implementation. Watershed models have been used for decades to study nonpoint-source pollution and the impact of non-structural BMPs, but a limited number of studies have

Submitted for review in December 2004 as manuscript number SW 5684; approved for publication by the Soil \& Water Division of ASABE in March 2006.

The authors are Kelsi S. Bracmort, ASABE Member, Engineering Program Specialist, USDA-NRCS, Washington, D.C.; Mazdak Arabi, ASABE Member Engineer, Research Associate, Jane R. Frankenberger, ASABE Member Engineer, Associate Professor, and Bernard A. Engel, ASABE Member, Professor, Department of Agricultural and Biologica Engineering, Purdue University, West Lafayette, Indiana; and Jeff G. Arnold, ASABE Member Engineer, Hydraulic Engineer, USDA-ARS Grasslands Soil and Water Research Laboratory, Temple, Texas. Corresponding author: B. A. Engel, Department of Agricultural and Biological Engineering, Purdue University, West Lafayette, IN 47907; phone: 765-494-1162; fax: 765-496-1115; e-mail: engelb@purdue.edu. examined the application of structural BMP simulation in watershed hydrology models.

The Soil and Water Assessment Tool (SWAT) predicts the impact of land management practices on water, sediment, and agricultural chemical yields in watersheds with varying soils, land use, and management conditions over time (Arnold et al., 1998). The continuous-time, process-based model requires specific information about weather, soil properties, topography, vegetation, presence of ponds or reservoirs, groundwater, the main channel, and land management practices.

The Black Creek Project in northeastern Indiana (1973 to 1984) implemented several structural management practices to identify BMPs that reduce sediment and phosphorus levels entering Lake Erie from agricultural activities (Morrison and Lake, 1983). The U.S. EPA provided about one million dollars to install and evaluate non-structural and structural BMPs and their impact on agricultural nonpoint-source pollution leaving the Black Creek watershed (Lake and Morrison, 1977b). Flow and water quality data were recorded for four years, encompassing the time period when practices were installed and continuing for a short time after all practices were installed.

A representative sample of grassed waterways, grade stabilization structures, field borders, and parallel terraces installed during the Black Creek Project had previously been inspected and assigned a condition score using evaluation tools developed for that purpose (Bracmort et al., 2004). Evaluation of the current condition of the BMPs found that one-third of the practices no longer exist today and that the two-thirds that still exist are in fair condition and are partially functional. However, water quality impacts of BMPs under good and existing conditions were not quantified in that study. 


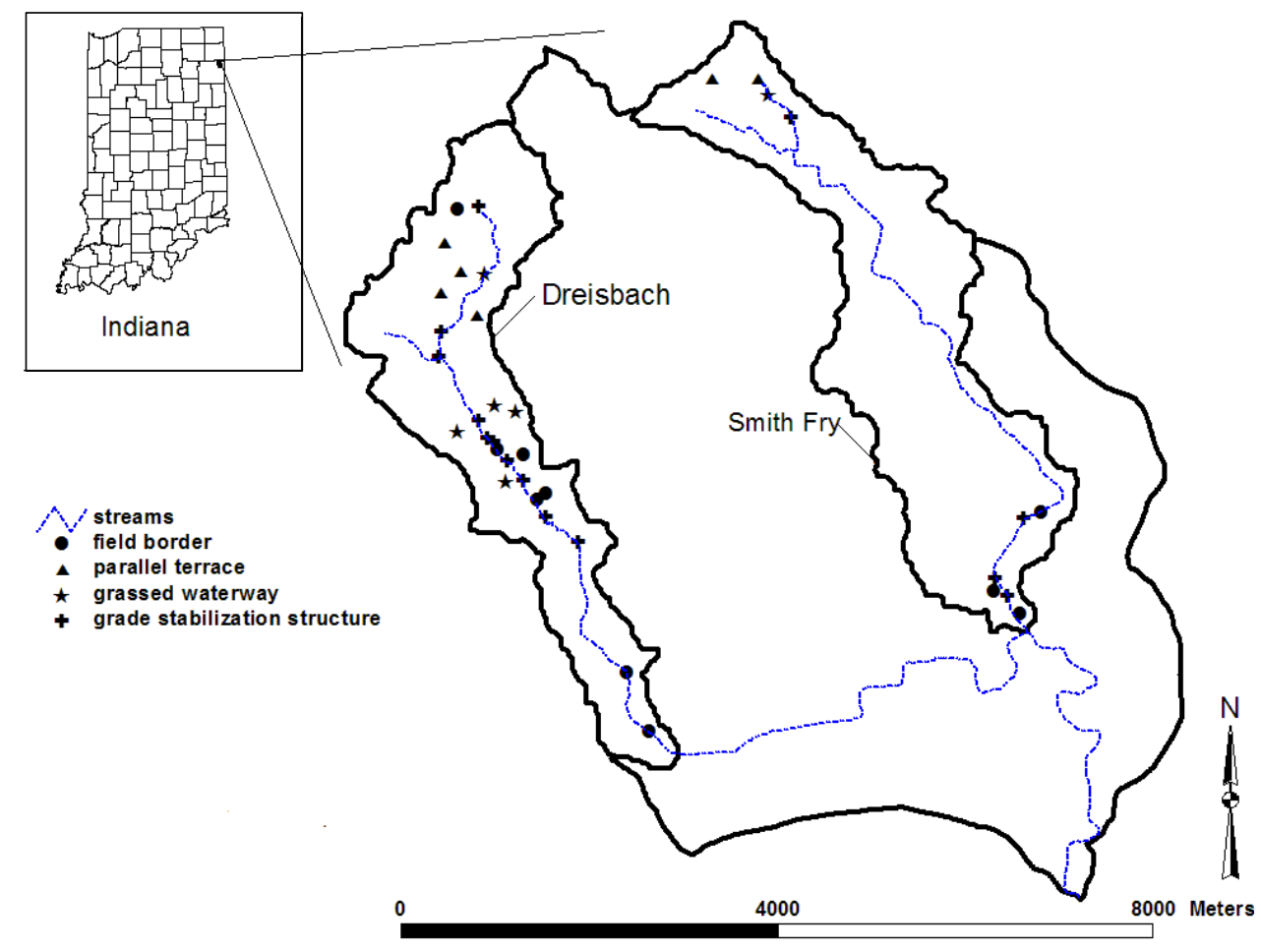

Figure 1. Smith Fry and Dreisbach location map and BMPs implemented.

The objective of this study was to analyze the long-term water quality impact of structural BMPs implemented during the Black Creek Project by developing a method to represent the functionality of structural BMPs in varying conditions in the SWAT model and then applying that method to the Black Creek watershed. Water quality studies conducted during the Black Creek Project, and the recent evaluation of a select group of practices, provide the opportunity to model the Black Creek watershed and to simulate BMP effects on the agricultural watershed close to 30 years after the initiation of the project.

\section{Methods And Materials WATERSHED DESCRIPTION}

The Black Creek watershed, roughly $50 \mathrm{~km}^{2}$ in size, is located in northeast Allen County, Indiana, about $24 \mathrm{~km}$ northeast of the city of Fort Wayne (fig. 1). The watershed is a tributary to the Maumee River, which flows northeast from Fort Wayne to Lake Erie, at Toledo, Ohio. In general, the soils are deep, ranging from moderately well drained to very poorly drained and medium to fine textured. The dominant hydrological soil group of soil series in the watershed is type C. Average annual rainfall for Fort Wayne is $928 \mathrm{~mm}$ (Indiana State Climatology Office, 2005). Topography for the watershed consists of mostly gently sloping land with an elevation of $256 \mathrm{~m}$ in the north and $228 \mathrm{~m}$ at the outlet. Row crop agriculture and pasture are the primary land uses in the watershed. Soybeans and corn are the main crops grown in the watershed, followed by winter wheat and other small grains (table 1).

Two drainage areas, Smith-Fry and Dreisbach, were used for monitoring and modeling (fig. 1). The Dreisbach watershed $\left(6.23 \mathrm{~km}^{2}\right)$ is located along the western border of the Black Creek watershed and contains more BMPs per unit area than the Smith Fry watershed $\left(7.30 \mathrm{~km}^{2}\right)$, which is located along the eastern border of the Black Creek watershed.

Watershed characteristics, management information, and BMP design information needed for BMP representation were collected for the mid to late 1970s for both watersheds. Observed water quality data for model calibration and validation purposes came from published Black Creek reports (Lake and Morrison, 1977a; Christensen and Wilson, 1981). Flow data were obtained from unpublished project literature. Data utilized for SWAT simulations are shown in table 2 and are available at http://pasture.ecn.purdue. edu/ blkcreek.

\section{BMP REPRESENTATION IN SWAT}

SWAT has previously been used to model the impact of structural BMPs in good condition. Vache et al. (2002) simulated riparian buffers, grassed waterways, filter strips, and field borders by modifying the channel cover factor and channel erodibility factor in SWAT to model the cover density and erosion resistance of the structures. Santhi et al. (2003) simulated grade stabilization structures in SWAT by modifying the slope and soil erodibility factor. The impact of filter strips on sediment and nutrient reduction was simulated

Table 1. Land use in the Dreisbach and Smith Fry watersheds.

\begin{tabular}{lcc}
\hline Land Use & $\begin{array}{c}\text { Dreisbach } \\
(\% \text { area })\end{array}$ & $\begin{array}{c}\text { Smith Fry } \\
(\% \text { area })\end{array}$ \\
\hline Pasture & 37.5 & 8.7 \\
Corn & 23.4 & 33.6 \\
Winter wheat & 17 & 14.3 \\
Soybean & 7.2 & 31.8 \\
Forest & 5.8 & 8.9 \\
Residential & 9.1 & 2.7 \\
\hline
\end{tabular}


Table 2. Model input data information (available at http://pasture.ecn.purdue.edu/ blkcreek).

\begin{tabular}{lll}
\hline Data Type (date) & Source & Description \\
\hline DEM (2001) & National elevation data & 30 m resolution, U.S. Geological Survey (USGS) \\
Soils (2002) & Soil Survey Geographic Database & Digital representation of county soil survey maps by the USDA-NRCS \\
Land use (1974-1978) & Black Creek Project & Digitized into GIS from aerial photos \\
Weather (1974-1977) & Black Creek Project documents ${ }^{[\mathrm{a}]}$ & Daily precipitation graphs \\
Weather (1970-2002) & Purdue Applied Meteorology Group & Minimum and maximum daily temperature and daily precipitation \\
Crop management & Engel and Lim (2001) & Management scenarios for crops \\
Streamflow (1975-1978) & Black Creek Project documents $\mathrm{S}^{\mathrm{b}]}$ & Daily streamflow \\
Water quality (1974-1977) & Black Creek Project documents $[\mathrm{c}]$ & Daily suspended solids, sediment P, soluble organic P, soluble inorganic $\mathrm{P}$ \\
\hline
\end{tabular}

[a] Lake and Morrison (1977a).

[b] Lake and Morrison (1977b).

[c] Morrison and Lake (1983).

as a function of filter strip width. However, these studies did not consider the change in BMP effectiveness as the condition deteriorates.

For this study, a method was developed to represent the ability of grassed waterways, grade stabilization structures, field borders, and parallel terraces in SWAT to reduce sediment occurring from non-gully erosion. The method was based on published literature pertaining to BMP simulation in hydrological models and considering the hydrologic and water quality processes simulated in SWAT.

Parallel terraces and field borders are implemented to reduce sheet and rill erosion from fields and other non-channel areas. SWAT utilizes the Modified Universal Soil Loss Equation (MUSLE) (Williams, 1975) to estimate sheet erosion for each hydrologic response unit (HRU). HRUs are portions of subwatersheds with unique soil, land use, and management attributes. Appropriate model parameters for representation of the effect of parallel terraces are the curve number (CN2) and USLE support practice factor (USLE P), along with slope length (SLSUBBSN). FILTERW (width of edge-of-field filter strip) was recognized to be the appropriate parameter for representation of field borders.

Implementation of grassed waterways and grade stabilization structures result in reduction of water flow and channel erosion in the channel network. Sediment deposition and degradation are two important channel processes that affect sediment yield at the outlet of the watershed. Key parameters for representing this effect are the channel Manning's coeffi- cient ( $\left.\mathrm{CH} \_\mathrm{N} 2\right)$, channel slope (CH_S2), channel erodibility factor ( $\left.\mathrm{C} \overline{\mathrm{H}} \_\mathrm{EROD}\right)$, and channel cover factor ( $\mathrm{CH}$ _COV). Parameters selected to represent the impact of each BMP, along with their estimated values in good condition and without the BMP, are listed in table 3. A sensitivity analysis was performed to ascertain the sensitivity of SWAT flow and water quality computations to the selected parameters.

After appropriate parameters were selected and sensitivity analyses validated their impact on SWAT predictions, the parameters were modified to represent BMPs in good and existing conditions. Parameter values for fair and poor condition were interpolated between values corresponding to BMPs in good condition and values with no BMP in place.

In running the model with BMPs represented as described above, the critical source area was selected to be small enough that most of the BMPs could be represented by a single sub-basin outlet. Critical source area refers to the minimum area required by the model for initiation of channel processes. For the five cases where multiple BMPs existed in a single sub-basin, practices were simulated by assigning one practice in the sub-basin to a certain land use or HRU and the other practice to another land use or HRU.

The current condition of a practice was simulated based on condition scores assigned to a subset of practices in the Black Creek watershed by using the evaluation tools described in Bracmort et al. (2004). The current condition of BMPs that were not physically inspected was assumed to be the average current condition score for that practice type.

Table 3. Representation of BMPs in SWAT.

\begin{tabular}{|c|c|c|c|c|}
\hline \multirow[b]{2}{*}{ BMP } & \multirow[b]{2}{*}{ Function } & \multicolumn{3}{|c|}{ Representative SWAT Parameter } \\
\hline & & Variable (input file) & $\begin{array}{l}\text { Value with no BMP } \\
\text { (from calibration) }\end{array}$ & $\begin{array}{l}\text { Value with BMPs } \\
\text { in good condition }\end{array}$ \\
\hline \multirow{3}{*}{ Grassed waterway } & Increase channel cover & CH_COV (.rch) & 0.2 & 0.0 \\
\hline & Reduce channel erodibility & CH_EROD (.rch) & 0.2 & 0.0 \\
\hline & Increasing channel roughness & CH_N(2) (.rch) & 0.04 & 0.24 \\
\hline \multirow{3}{*}{ Parallel terrace } & Reduce overland flow & $\mathrm{CN}(2) \quad(. \mathrm{mgt})$ & Assigned by SWAT ${ }^{[a]}$ & $-[\mathrm{b}]$ \\
\hline & Reduce sheet erosion & USLE_P (.mgt) & 0.3 & 0.2 \\
\hline & Reduce slope length & SLSUBBSN (.hru) & Assigned by SWAT[c] & $--[\mathrm{d}]$ \\
\hline Field border & Increase sediment trapping & FILTERW (.hru) & 0 & $5(\mathrm{~m})$ \\
\hline \multirow[t]{2}{*}{ Grade stabilization structure } & Reduce gully erosion & CH_EROD (.rch) & 0.2 & 0.0 \\
\hline & Reduce slope steepness & CH_S(2) (.rch) & Assigned by SWAT[c] & $-\_[\mathrm{e}]$ \\
\hline
\end{tabular}

[a] Assigned by SWAT based on hydrologic soil group, land use, and antecedent moisture condition.

[b] Obtained from SWAT user's manual (version 2000) for contoured and terraced condition (based on land treatment and hydrologic soil group).

[c] Assigned by SWAT based on the digital elevation model (DEM).

[d] Estimated for each parallel terrace based on its features and SWAT-assigned overland slope of the HRU where it is installed: SLSUBBSN $=(\mathrm{A} \times \mathrm{S}+\mathrm{B}) \times 100 / \mathrm{S}$, where $\mathrm{S}$ is average slope of the HRU, $\mathrm{A}=0.21$, and $\mathrm{B}=0.9$ (ASAE Standards, 2003).

[e] Estimated for each grade stabilization structure based on its features and SWAT-assigned slope and length of the channel segment where it is installed: CH_S(2) = CH_S(2)SWAT assigned $-\mathrm{D} / \mathrm{CH} \_\mathrm{L}(2)$, where D is height of the structure $(1.2 \mathrm{~m})$, and $\mathrm{CH} \_\mathrm{L}(2)$ is length of the channel segment. 


\section{SENSITIVITY ANALYSIS}

The SWAT model outputs depend on many input parameters related to the soil, land use, management, weather, channels, aquifer, and reservoirs. Therefore, modeling BMPs with SWAT necessitates evaluation of the sensitivity of SWAT flow, sediment, and nutrient outputs to the selected parameters for representation of BMPs. Table 4 summarizes 30 SWAT parameters selected for sensitivity analysis in this study. These parameters were chosen based on the results of previous studies by Arnold et al. (2000), Eckhardt and Arnold (2001), Santhi et al. (2001), and Santhi et al. (2003). Sensitivity of streamflow, sediment, and phosphorus outputs of the SWAT model to the selected parameters was sought by perturbing model parameters "one at a time" and determining a linear sensitivity parameter $\left(S_{i}\right)$, defined as (adapted from $\mathrm{Gu}$ and $\mathrm{Li}, 2002$ ):

$$
S_{i}=\frac{\left(y_{2}-y_{1}\right) /\left(y_{2}+y_{1}\right)}{\left(\alpha_{i, 2}-\alpha_{i, 1}\right) /\left(\alpha_{i, 2}+\alpha_{i, 1}\right)}
$$

where $y_{1}$ and $y_{2}$ are model outputs corresponding to perturbation of the $i$ th element of the parameter vector from $\alpha_{i, 1}$ to $\alpha_{i, 2}$, while other parameters were kept constant. In equation 1 , it is assumed that the response of model outputs to parameter perturbation is linear. $S_{i}$ is essentially a normalized estimate of sensitivity of design variables (streamflow, sediment yield, etc.) to a parameter perturbation, with higher values indicating higher sensitivity. Parameters with high sensitivity were also chosen for model calibration.

\section{Model Calibration and Validation}

Model calibration and validation were performed for monthly streamflow, surface runoff, sediment, mineral phosphorus, and total phosphorus using rainfall, flow, and water quality input data collected for the time when the BMPs were installed and for a few years after implementation. The Dreisbach watershed was calibrated with the inclusion of 26 BMPs (5 grassed waterways, 10 grade stabilization structures, 7 field borders, and 4 parallel terraces) using the representation method for BMPs in good condition, since documentation indicated these were installed in the first phase of the project, the early to mid-1970s, prior to collection of observed water quality data (Morrison and Lake, 1983). The Smith Fry watershed was calibrated without BMPs because these 10 BMPs (1 grassed waterway, 4 grade stabilization structures, 3 field borders, and 2 parallel terraces) were implemented in the late 1970s (fig. 1).

Calibration involved comparing average monthly simulated and observed values, and computing the Nash-Sutcliffe efficiency $\left(\mathrm{E}_{\mathrm{N}-\mathrm{S}}\right)$ (Nash and Sutcliffe, 1970) and coefficient of determination $\left(\mathrm{R}^{2}\right)$ between observed and simulated values. Model calibration was considered satisfactory if the simulated quantity was within $20 \%$ of observed data, $\mathrm{R}^{2}$ was greater than 0.6, and $\mathrm{E}_{\mathrm{N}-\mathrm{S}}$ was greater than 0.5.

Once calibration of the model was completed, validation was performed to evaluate the accuracy of the model to predict values from an observational data set different from the calibration data (Wilson, 2002). Model validation used optimal parameter values selected during model calibration

Table 4. List of SWAT parameters considered in sensitivity analysis.

\begin{tabular}{|c|c|c|c|c|}
\hline Parameter & Short Description & Minimum & Maximum & Units \\
\hline $\mathrm{CN} 2$ & Initial SCS runoff curve number & 35 & 98 & -- \\
\hline SLOPE & Average slope steepness & 0 & 0.6 & $\mathrm{~m} / \mathrm{m}$ \\
\hline SLSUBBSN & Average slope length & 10 & 150 & $\mathrm{~m}$ \\
\hline ESCO & Soil evaporation compensation factor & 0 & 1 & -- \\
\hline $\mathrm{CH}-\mathrm{N} 1$ & Manning's " $\mathrm{n}$ " value for tributary channels & 0.008 & 30 & -- \\
\hline CH-S1 & Average slope of tributary channels & 0 & 10 & $\mathrm{~m} / \mathrm{m}$ \\
\hline $\mathrm{CH}-\mathrm{K} 1$ & Effective hydraulic conductivity in tributary channel alluvium & 0 & 150 & $\mathrm{~mm} / \mathrm{h}$ \\
\hline $\mathrm{CH}-\mathrm{N} 2$ & Manning's " $n$ " value for the main channel & 0.008 & 0.3 & -- \\
\hline $\mathrm{CH}-\mathrm{S} 2$ & Average slope of the main channel & 0 & 10 & $\mathrm{~m} / \mathrm{m}$ \\
\hline $\mathrm{CH}-\mathrm{K} 2$ & Effective hydraulic conductivity in main channel & 0 & 150 & $\mathrm{~mm} / \mathrm{h}$ \\
\hline GWQMN & Threshold depth of water in shallow aquifer & 0 & 5000 & $\mathrm{~mm}$ \\
\hline ALPHA-BF & Baseflow alpha factor & 0 & 1 & days \\
\hline GW-DELAY & Groundwater delay time & 0 & 500 & days \\
\hline GW-REVAP & Groundwater "revap" time & 0.02 & 0.2 & -- \\
\hline SOL-AWC & Available water capacity of the soil layer & 0 & 1 & $\mathrm{~mm} / \mathrm{mm}$ \\
\hline CH_EROD & Channel erodibility factor & 0 & 0.6 & $\mathrm{~cm} / \mathrm{h} / \mathrm{Pa}$ \\
\hline CH_COV & Channel cover factor & 0 & 1 & -- \\
\hline SPCON & Linear coefficient for sediment routing & 0.001 & 0.01 & -- \\
\hline SPEXP & Exponent coefficient for sediment routing & 1 & 1.5 & -- \\
\hline PRF & Peak rate adjustment factor for sediment routing & 0 & 2 & -- \\
\hline USLE_P & USLE equation support practice factor & 0.1 & 1 & -- \\
\hline USLE_C & Maximum value of USLE equation cover factor & 0.001 & 0.5 & -- \\
\hline SOL_L̄ABP & Initial soluble $\mathrm{P}$ concentration in soil layer & 0 & 100 & $\mathrm{mg} / \mathrm{kg}$ \\
\hline SOL_ORGP & Initial organic $\mathrm{P}$ concentration in soil layer & 0 & 4000 & $\mathrm{mg} / \mathrm{kg}$ \\
\hline $\mathrm{RS}^{-}$ & Local algae settling rate at $20^{\circ} \mathrm{C}$ & 0 & 2 & $\mathrm{~m} /$ day \\
\hline RS2 & Benthic (sediment) source rate for dissolved $\mathrm{P}$ & 0.001 & 0.1 & $\mathrm{mg} / \mathrm{m}^{2} \cdot$ day \\
\hline RS5 & Organic $\mathrm{P}$ settling rate in the reach at $20^{\circ} \mathrm{C}$ & 0.001 & 0.1 & 1/day \\
\hline BC4 & Rate constant for mineralization of $\mathrm{P}$ to dissolved $\mathrm{P}$ & 0 & 1 & 1/day \\
\hline AI0 & Ratio of chlorophyll-a to algae biomass & 0.001 & 0.01 & $\mu \mathrm{g} / \mathrm{mg}$ \\
\hline AI2 & Fraction of algal biomass that is phosphorus & 0.01 & 0.02 & $\mathrm{mg} \mathrm{P} / \mathrm{mg}$ al \\
\hline RHOQ & Algal respiration rate at $20^{\circ} \mathrm{C}$ & 0.05 & 0.5 & 1/day \\
\hline
\end{tabular}


for a number of months following the calibration time period. Predicted and observed data were compared using $\mathrm{E}_{\mathrm{N}-\mathrm{S}}$ and $\mathrm{R}^{2}$ to test model validity.

\section{MODEL RunS}

Model simulations were performed to quantify the long-term impact of the BMPs in good and current conditions on water quality over a 25-year period (1975-2000). Each watershed was simulated for 25 years with no BMPs (baseline case), BMPs in good condition, and BMPs in varying condition (representing their existing condition). Predicted sediment and total $\mathrm{P}$ for these scenarios were compared to analyze the impact of BMP presence and BMP condition on water quality. All inputs were held constant except for the presence and condition of BMPs.

\section{RESULTS}

Results indicated that SWAT outputs, computed at the outlet of the study watersheds, were sensitive to the parameters selected for representation of BMPs. Figure 2 depicts the sensitivity of streamflow, sediment yield, and total P outputs of the SWAT model to the parameters listed in table 4. The magnitude of the sensitivity index, $S_{i}$ (eq. 1), corresponding to each model parameter is subject to the initial set of parameters that are used in the analysis. Figure $2 \mathrm{~b}$ illustrates the sensitivity of sediment output of SWAT to various input parameters listed in table 4 for two cases. In the first case, the default value was used for the USLE practice factor, i.e., USLE_P $=1$. It was observed that in this case the parameters that affect the magnitude of channel degradation, such as PRF, $\mathrm{CH}$ _COV, and CH_EROD (see table 4), did not bear a high sensitivity for sediment outputs. However, when the USLE practice factor was altered to 0.3 , i.e., USLE_P $=0.3$, the parameters corresponding to sediment transport in the channel network were among the most sensitive parameters, as demonstrated in figure $2 \mathrm{~b}$. The sensitivity index for parameter FILTERW, which was used for representation of field borders (not shown in fig. 2), was 0.35 and 0.72 for sediment and total $\mathrm{P}$, respectively. Therefore, sediment and total P outputs of the SWAT model were sensitive to all of the parameters selected for representation of parallel terraces, field borders, grassed waterways, and grade stabilization structures.

Satisfactory model calibration and validation results were obtained for both watersheds, as evaluated by the Nash-Sutcliffe $\left(\mathrm{E}_{\mathrm{N}-\mathrm{S}}\right)$ and coefficient of determination $\left(\mathrm{R}^{2}\right)$ values (tables 5 and 6, figs. 3 and 4). The calibrated model was able to adequately predict both low and high streamflows and sediment yields in both watersheds except for March 1978, for which streamflows were underpredicted. While the model slightly overpredicted mineral and total phosphorus yields at the outlets for the months with low phosphorus
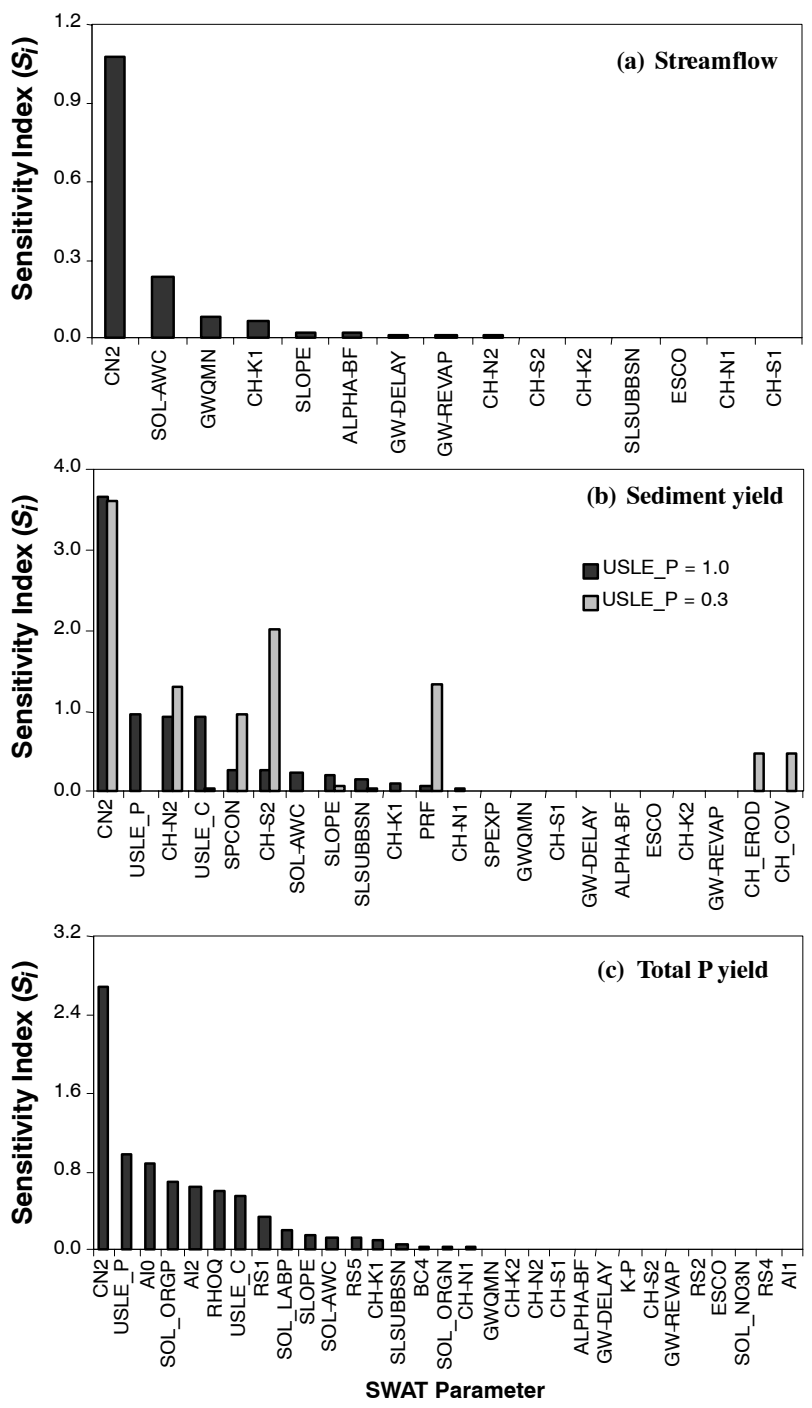

Figure 2. Sensitivity of SWAT parameters in table 4, determined based on (a) streamflow, (b) sediment, and (c) total P.

yields, the high-yield months were underpredicted. The calibrated model was used to evaluate the impact of BMPs on streamflow, sediment, and total $\mathrm{P}$ yields at the outlet of the study watersheds.

\section{STREAMFLOW}

Runoff volume and streamflow at the outlet of the Dreisbach and Smith Fry watersheds were not affected by implementation of BMPs. This was anticipated, because BMP selection was targeted at sediment and phosphorus reduction. Parallel terraces, the only type of BMPs in the study area that influence runoff prediction parameters (overland slope and curve number), cover less than $2 \%$ of the

Table 5. Results of calibration of SWAT for average monthly streamflow, sediment, and nutrients.

\begin{tabular}{|c|c|c|c|c|c|c|c|c|}
\hline \multirow[b]{2}{*}{ Variable } & \multicolumn{4}{|c|}{ Dreisbach (Site 6) } & \multicolumn{4}{|c|}{ Smith Fry (Site 2) } \\
\hline & Observed & Simulated & $\mathrm{R}^{2}$ & $\mathrm{E}_{\mathrm{N}-\mathrm{S}}$ & Observed & Simulated & $\mathrm{R}^{2}$ & $\mathrm{E}_{\mathrm{N}-\mathrm{S}}$ \\
\hline Streamflow (mm) & 16 & 17 & 0.92 & 0.84 & 19 & 18 & 0.86 & 0.73 \\
\hline Surface runoff (mm) & 15 & 15 & 0.91 & 0.80 & 16 & 18 & 0.84 & 0.62 \\
\hline Suspended solids (t/ha) & 0.027 & 0.024 & 0.97 & 0.92 & 0.151 & 0.16 & 0.94 & 0.86 \\
\hline Mineral P (kg/ha) & 0.070 & 0.070 & 0.92 & 0.84 & 0.071 & 0.071 & 0.9 & 0.78 \\
\hline Total P (kg/ha) & 0.077 & 0.094 & 0.93 & 0.78 & 0.075 & 0.068 & 0.64 & 0.51 \\
\hline
\end{tabular}


Table 6. Results of validation of SWAT for average monthly streamflow, sediment, and nutrients.

\begin{tabular}{|c|c|c|c|c|c|c|c|c|}
\hline \multirow[b]{2}{*}{ Variable } & \multicolumn{4}{|c|}{ Dreisbach (Site 6) } & \multicolumn{4}{|c|}{ Smith Fry (Site 2) } \\
\hline & Observed & Simulated & $\mathrm{R}^{2}$ & $\mathrm{E}_{\mathrm{N}-\mathrm{S}}$ & Observed & Simulated & $\mathrm{R}^{2}$ & $\mathrm{E}_{\mathrm{N}-\mathrm{S}}$ \\
\hline Streamflow (mm) & 17 & 19 & 0.87 & 0.73 & 18 & 23 & 0.81 & 0.63 \\
\hline Surface runoff (mm) & 16 & 18 & 0.88 & 0.75 & 15 & 22 & 0.84 & 0.63 \\
\hline Suspended solids (t/ha) & 0.032 & 0.033 & 0.86 & 0.75 & 0.052 & 0.073 & 0.85 & 0.68 \\
\hline Mineral P (kg/ha) & 0.067 & 0.067 & 0.86 & 0.74 & 0.139 & 0.133 & 0.73 & 0.51 \\
\hline Total P (kg/ha) & 0.074 & 0.09 & 0.90 & 0.79 & 0.241 & 0.159 & 0.73 & 0.37 \\
\hline
\end{tabular}
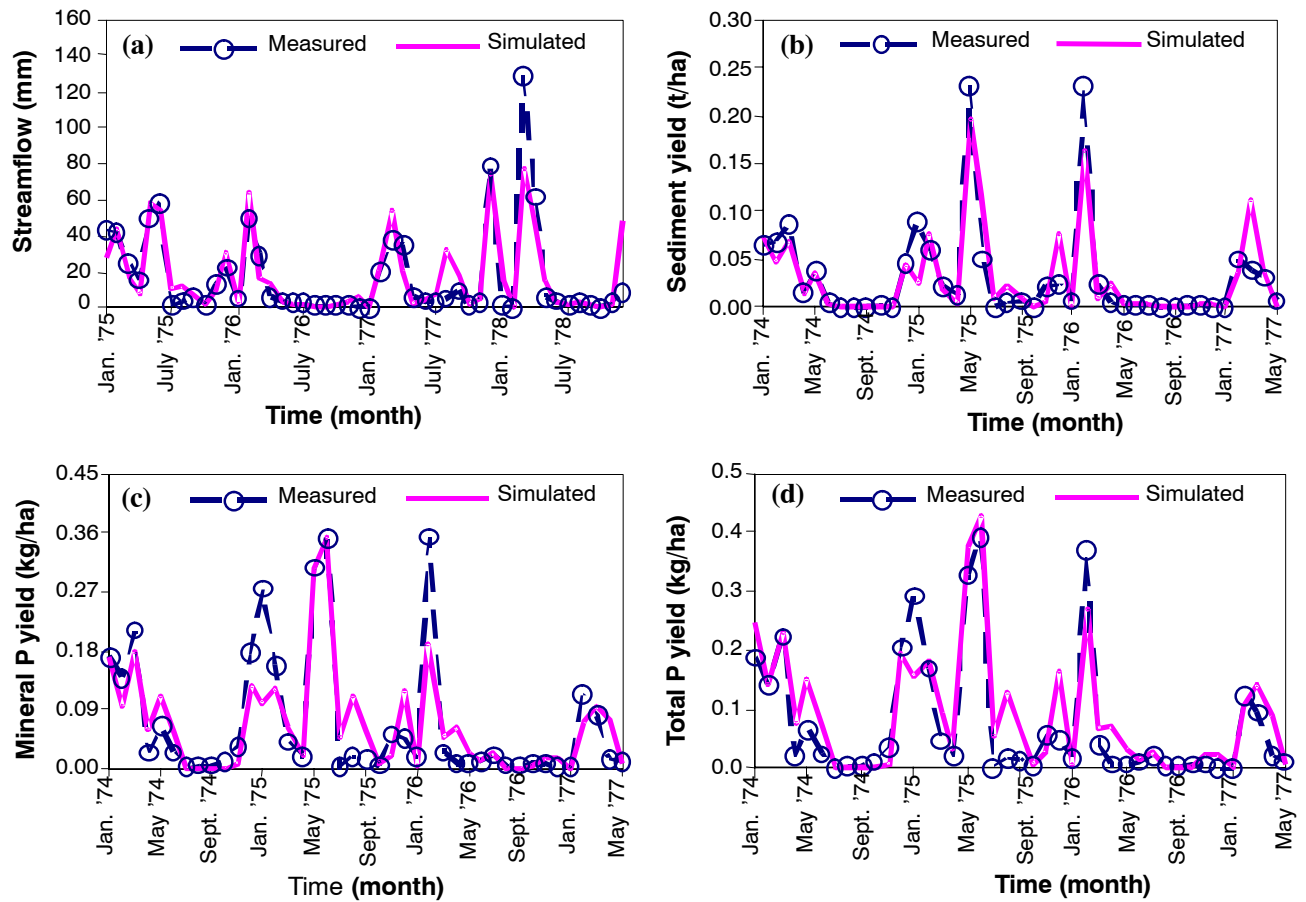

Figure 3. Observed and predicted monthly (a) streamflow, (b) sediment, (c) mineral phosphorus, and (d) total phosphorus values, calibration and validation period, Dreisbach watershed.
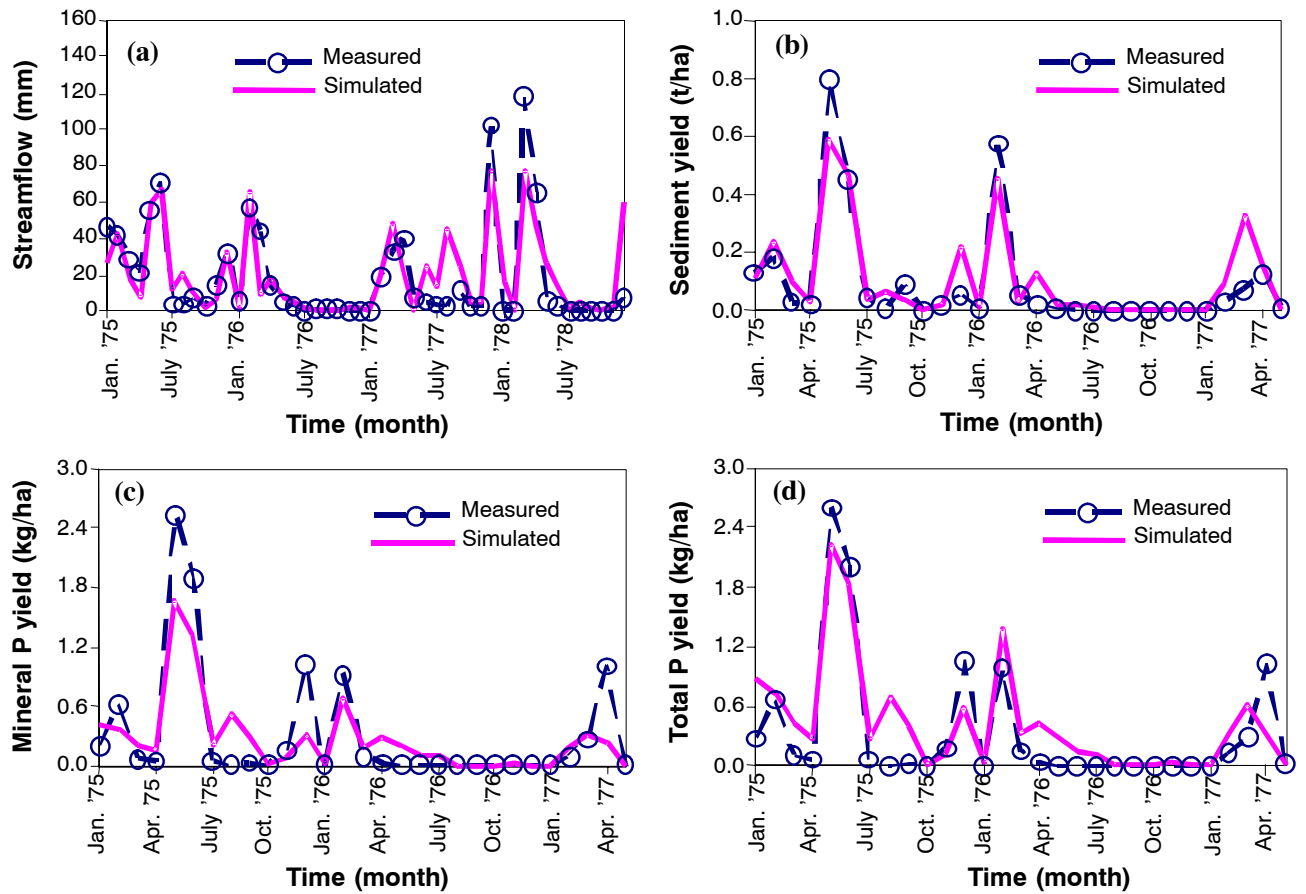

Figure 4. Observed and predicted monthly (a) streamflow, (b) sediment, (c) mineral phosphorus, and (d) total phosphorus values, calibration and validation period, Smith Fry watershed. 
Table 7. Annual predicted sediment yield for 1975-2000 from the Dreisbach and Smith Fry watersheds.

\begin{tabular}{|c|c|c|c|c|c|c|c|c|}
\hline \multirow{2}{*}{$\begin{array}{l}\text { BMP } \\
\text { Condition }\end{array}$} & \multicolumn{4}{|c|}{ Dreisbach (t/ha) } & \multicolumn{4}{|c|}{ Smith Fry (t/ha) } \\
\hline & Mean & SD & Max. & Min. & Mean & $\mathrm{SD}$ & Max. & Min. \\
\hline No BMP & 0.68 & 0.39 & 1.72 & 0.15 & 1.07 & 0.58 & 2.95 & 0.34 \\
\hline Good & 0.46 & 0.26 & 1.14 & 0.10 & 0.90 & 0.48 & 2.42 & 0.28 \\
\hline Varying & 0.61 & 0.34 & 1.54 & 0.12 & 0.99 & 0.53 & 2.73 & 0.31 \\
\hline
\end{tabular}

study area. Thus, their impact on streamflow at a watershed scale was negligible.

\section{SEDIMENT}

Annual sediment yield at the outlet of the Dreisbach and Smith Fry watersheds is summarized in table 7. Comparing model outputs for BMPs under good and varying conditions with outputs for the baseline scenario (no BMP) reveals the efficacy of the BMPs in various conditions. Operation of the BMPs under good condition would reduce the average annual sediment yield from the Dreisbach watershed by approximately $32 \%$, from $0.68 \mathrm{t} / \mathrm{ha}$ to $0.46 \mathrm{t} / \mathrm{ha}$. The reduction rate for the BMPs in varying condition was nearly $10 \%$. Predicted sediment yield in Smith Fry was decreased by about $16 \%$ and $7 \%$ under good and varying conditions, respectively. Differences in efficacies of the BMPs in the two watersheds may be because the number of BMPs installed in the Smith Fry watershed is significantly less than the number in the Dreisbach watershed.

Reduction in maximum annual sediment yields from the watersheds (table 7) indicates results similar to those for the average annual sediment yields. This further validates the flexibility of the proposed BMP representation method, suggesting that the method was not only capable of representing BMPs under average annual conditions but could also represent the BMPs under high sediment yield conditions.

\section{Total $\mathbf{P}$}

A summary of the annual phosphorus outputs of the SWAT model for these scenarios is provided in table 8. Results show that phosphorus yield at the outlet of the Dreisbach watershed decreased by nearly $25 \%$ (from 1.03 to $0.78 \mathrm{~kg} / \mathrm{ha}$ ) due to BMPs in good condition, while this reduction was about $10 \%$ at the Smith Fry outlet. Corresponding reductions for the scenario with BMPs in varying condition were nearly $17 \%$ at the Dreisbach watershed and 7\% at the Smith Fry watershed.

Reduction in total P load was consistent with the reduction of sediment yield at the outlet of the watersheds. This was anticipated for two reasons. First, in relatively small watersheds like Dreisbach and Smith Fry $\left(<10 \mathrm{~km}^{2}\right)$, the role of in-stream nutrient processes that are simulated by SWAT, such as algal decay on phosphorus yield, is negligible compared to soil loss from upland areas and channel erosion. In such watersheds, it can be claimed that sediment and phosphorus yields are correlated. The correlation coefficient

Table 8. Annual predicted total $P$ yield for $1975-2000$ from the Dreisbach and Smith Fry watersheds.

\begin{tabular}{|c|c|c|c|c|c|c|c|c|}
\hline \multirow{2}{*}{$\begin{array}{l}\text { BMP } \\
\text { Condition }\end{array}$} & \multicolumn{4}{|c|}{ Dreisbach (kg/ha) } & \multicolumn{4}{|c|}{ Smith Fry (kg/ha) } \\
\hline & Mean & SD & Max. & Min. & Mean & SD & Max. & Min. \\
\hline No BMP & 1.03 & 0.47 & 2.21 & 0.45 & 0.99 & 0.45 & 2.37 & 0.44 \\
\hline Good & 0.78 & 0.35 & 1.62 & 0.34 & 0.89 & 0.41 & 2.12 & 0.39 \\
\hline Varying & 0.85 & 0.39 & 1.79 & 0.36 & 0.92 & 0.42 & 2.22 & 0.40 \\
\hline
\end{tabular}

$\left(\mathrm{R}^{2}\right)$ between measured monthly sediment yield and total P load at the outlets of the Dreisbach and Smith Fry watersheds was 0.79. Moreover, BMPs installed in the study watersheds were basically sediment control structures. Impact of BMPs on total P load was a result of reduction of sediment yield.

\section{DisCuSSION}

BMPs in varying condition were represented by modifying model parameters by interpolation between those for no BMPs and those for BMPs in good condition. Interpolation is subjective and varies with investigation methods. Parameter values for intermediate conditions (fair and poor) should be further investigated.

BMPs were represented in this study by modifying some model parameters selected based on function and then performing sensitivity analysis at both hydrologic response unit (HRU) and watershed scales. A complementary uncertainty analysis could provide more insights in identification of control processes and key management actions in the watershed.

Finally, the method presented in this study should also be validated on watersheds of different scales. Because outputs of the SWAT model are affected by the number and size of subwatersheds, predicted performance of BMPs will be influenced by watershed size and discretization level. Thus, this study would be strengthened by validating the BMP representation methods at multiple discretization levels and spatial scales.

\section{Conclusions}

Long-term ( 25 year) impact of structural BMPs installed during the Black Creek Project in the 1970s and early 1980s was estimated through the use of SWAT. A BMP representation method was developed for grassed waterways, grade stabilization structures, field borders, and parallel terraces in good condition and in varying condition. The method was used to analyze sediment and total phosphorus reduction occurring from non-gully erosion due to BMP implementation in the watershed. In this study, two watersheds were studied to further validate model calibration results. In addition, the versatility and flexibility of the developed modeling approach for representation of BMPs was tested by applying the same method on two watersheds with different numbers of BMPs.

Installation of parallel terraces and field borders reduced predicted sediment and phosphorus loss from upland (nonchannel) areas. Grade stabilization structures and grassed waterways reduced erosion of the channel network, and thus sediment and phosphorus yields at the outlet were reduced. Efficacy of BMPs in reducing nonpoint-source pollution varied with their condition. Under good conditions, BMPs in the Dreisbach watershed, where a sufficient number of BMPs were installed, alleviated average annual sediment and phosphorus yields at the outlet by $32 \%$ and $24 \%$, respectively. As BMPs deteriorate, their ability to reduce sediment and total $\mathrm{P}$ diminishes. Modeling results for BMPs in varying conditions revealed that the average annual sediment yield was reduced by only $10 \%$, which is nearly 3 times less than the reduction corresponding to BMPs in good condition. 
Estimated average annual phosphorus yield at the outlet of the Dreisbach watershed was reduced by $17 \%$ for BMPs in their current condition, providing nearly $70 \%$ of the phosphorus reduction estimated for BMPs in good condition.

\section{ACKNOWLEDGEMENTS}

The authors thank R. Srinivasan, C. Santhi, and M. Di Luzio for their assistance with SWAT.

\section{REFERENCES}

Arnold, J. G., Muttiah, R. S., Sirinivasan, R., and P. M. Allen. 2000. Regional estimation of base flow and groundwater recharge in the Upper Mississippi river basin. J. Hydrology 227: 21-40.

Arnold, J. G., R. Srinivisan, R. S. Muttiah, and P. M. Allen. 1998. Large-area hydrologic modeling and assessment: Part I. Model development. J. American Water Resources Assoc. 34(1):73-89.

ASAE Standards. 2003. S268.4: Design, layout, construction, and maintenance of terrace systems. St. Joseph, Mich.: ASAE.

Bracmort, K., B. Engel, and J. Frankenberger. 2004. Evaluation of structural best management practices 20 years after installation: Black Creek watershed, Indiana. J. Soil and Water Cons. 59(5): 191-196.

Christensen, R., and C. Wilson. 1981. Environmental impact of land use on water quality: Final report on the Black Creek Project Phase II. EPA-905/9-81-00. Chicago, Ill.: U.S. Environmental Protection Agency.

Eckhardt, K., and J. G. Arnold. 2001. Automatic calibration of a distributed catchments model. J. Hydrology 251(1-2): 103.

Engel, B., and K. J. Lim. 2001. Estimating nutrient losses within Indiana. West Lafayette, Ind.: Purdue University, Department of Agricultural and Biological Engineering. Available at: http://danpatch.ecn.purdue.edu/ napra/napra_nutrients_results_f or_indiana/nu_input.html.

Gu, R., and Y. Li. 2002. River temperature sensitivity to hydraulic and meteorological parameters. J. Environ. Management 66(1): 43-56.

Indiana State Climatology Office. 2005. Monthly normal precipitation for Indiana database. Available at: http://agmetx.agry.purdue.edu/sc.norm-geog.html.
Lake, J., and J. Morrison. 1977a. Environmental impact of land use on water quality final report on the Black Creek project Technical report. EPA 905/9-77-007-B. Chicago, Ill.: U.S. Environmental Protection Agency.

Lake, J. and J. Morrison. 1977b. Environmental impact of land use on water quality - Final report on the Black Creek project (project data). EPA-905/9-77-007-C. Chicago, Ill.: U.S. Environmental Protection Agency.

Morrison, J., and J. Lake. 1983. Environmental impact of land use on water quality Black Creek project - Final report. Fort Wayne, Ind.: Allen County Soil and Water Conservation District.

Nash, J. E., and J. V. Sutcliffe. 1970. River flow forecasting through conceptual models: Part I. Discussion of principles. J. Hydrology 10(3): 282-290.

Santhi, C., J. G. Arnold, J. R. Williams, W. A. Dugas, R. Sirinivasan, and L. M. Hauck. 2001. Validation of the SWAT model on a large river basin with point and nonpoint sources. $J$. American Water Resources Assoc. 37(5): 1169-1188.

Santhi, C., R. Srinivasan, J. G. Arnold, and J. R. Williams. 2003. A modeling approach to evaluate the impacts of water quality management plans implemented in the Big Cypress Creek watershed. In Proc. Conference: Total Maximum Daily Load (TMDL) Environmental Regulations - II, 384-394. A. Saleh, ed. St. Joseph, Mich.: ASAE.

USDA-NRCS. 2004. Indiana state average costs per practice 2004. Available at: www.in.nrcs.usda.gov/technical/planning/2004_CostList.xls. Accessed 16 December 2004.

Vache, K., J. Eilers, and M. Santelmann. 2002. Water quality modeling of alternative agricultural scenarios in the U.S. corn belt. J. American Water Resources Assoc. 38(3): 773-787.

Williams, J. R. 1975. Sediment-yield prediction with universal equation using runoff energy factor. In Proc. Sediment Yield Workshop: Present and Prospective Technology for Predicting Sediment Yield and Sources, 244-252. ARS-S-40. Oxford, Miss.: USDA Sedimentation Laboratory.

Wilson, B. N. 2002. Good calibration and validation practices for hydrologic and water quality models. ASAE Paper No. 022294. St. Joseph, Mich.: ASAE. 